\title{
LABELLING OF PROTEIN FRACTIONS OF FASCIOLA HEPATICA ANTIGEN WITH ${ }^{125 I}$
}

\author{
J. TOMÁNEK, J. HAMPL, M. SEDLÁČEK, J. WILLOMITZER and E. CHROUSTOVÁ \\ Veterinary Research Institute, 62132 Brno
}

Received fuly 28, 1980

\begin{abstract}
Tománek J., J. Hampl, M. Sedláček, J. Willomitzer and E. Chroustová: Labelling of Protein Fractions of Fasciola hepatica Antigen with ${ }^{125}$ I. Acta vet. Brno, 50, 1981: 97-100.

Gel filtration of crude Fasciola hepatica antigen on Sephadex G-100 and G-200 yielded protein fractions that reacted with serum antibodies of $F$. hepatica - infected animals. The fractions were labelled with ${ }^{125} \mathrm{I}$ by the oxidation method using chloramine T. The protein-bound radioiodine percentage was 5.4 to 23.6 per cent, depending on the quality of flukes employed for the preparation of crude antigen and on the $\mathrm{Na}{ }^{125} \mathrm{I}$ employed for iodination. When tested by direct radioimmunodiffusion with positive sera from $F$. hepatica-infected animals and with control negative sera, the ${ }^{125}$ I-labelled protein fractions showed the same specificity as the unlabelled ones. The iodinated antigen was stable for 4 weeks, and no more than 5 and 6 per cent of unreacted radioactive iodide were found after 6 and 8 weeks of storage, respectively. Stored at $4{ }^{\circ} \mathrm{C}$, the iodinated antigen could be used for serological reactions for 5 to 8 weeks.
\end{abstract}

Diagnosis, fascioliasis, direct radioimmunodiffusion, protein-bound radioiodine percentage, stability, iodinated antigen.

The diagnosis of fascioliasis by serological methods has been described by a number of investigators using differently prepared antigens with varying results. The pertinent literature was reviewed by Koch (1969) and Grelck (1976). The possibility of demonstrating the antibodies by radioimmunoassay (RIA) has not been considered to date. One of the prerequisites for successful RIA is the use of a suitable antigen. Crude antigen obtained from Fasciola hepatica homogenate can be conveniently fractionated by gel filtration on a Sephadex column of appropriate type as was demonstrated by Movsesijan and Borojević (1973). The relatively specific protein fraction separated in this way can be labelled with an radioactive isotope and used for RIA. For practical purposes it appears most convenient to use ${ }^{125}$ I which was employed by Williams et al. (1971) for the labelling of Schistosoma mansoni antigen.

Our objective was to separate the functional fraction from crude $F$. hepatica antigen, to test the conditions of its labelling by the oxidation method with chloramine $T$ and to assess the properties of the iodinated antigen.

\section{Materials and Methods}

The antigen was prepared from adult $F$. hepatica obtained from the liver of infected animals. The flukes were washed in several changes of saline, dried of filter paper and frozen at $-18^{\circ} \mathrm{C}$. After being thawed, they were ground in a glass homogenizer, macerated in saline for 24 hours at +4 to $+6{ }^{\circ} \mathrm{C}$ and then centrifugated for $20 \mathrm{~min}$. at $12000 \mathrm{r}$. p. m. The supernatant was aspirated and used for the separation of fractions by gel filtration on a $2.5 \times 39 \mathrm{~cm}$ column of Sephadex G-100 or an a $2.5 \times 85 \mathrm{~cm}$ column of Sephadex G-200. Elution was carried out with $0.15 \mathrm{~mol} / 1$ $\mathrm{NaCl}, \mathrm{pH} 7.0$, or $0.2 \mathrm{~mol} / 1$ Tris $\mathrm{HCl}$ buffer, $\mathrm{pH}$ 8.0 Fractions obtained from the individual peaks were concentrated under a cold air flow in dialysis tubes and then tested by diffusion in agar gel according to Ouchterlony using rabbit and sheep sera containing antibodies produced in response 
to infection with $F$. hepatica. The fractions that reacted with positive sera were pooled and the protein was determined quantitatively according to Lowry et al. (1951). These fractions were labelled with ${ }^{125}$ iodine according to McConahey and Dixon (1966). Unreacted radioactive iodide was removed by dialysis against buffered saline, $\mathrm{pH}$ 7.2. Checks upon the completeness of its removal were carried out by ascending paper chromatography according to Schmidt et al. (1979) and the results were evaluated by measurement in an Actigraph III, Nuclear Chicago.

Antigenic specificity of the ${ }^{125}$ I-labelled fractions was checked by direct radioimmunodiffusion with antibody-containing sera from $F$. hepatica-infected animals and with negative sera. The results were evaluated autoradiographically using a Medix Rapid R3 film, Foma, at an exposure time of 24 to 72 hours.

\section{Results}

Gel filtration on Sephadex G-100 of the crude antigen obtained by maceration of the $F$. hepatica homogenate in saline yielded, for the most part, 4 fractions (Fig. 1). Immunoelectrophoresis revealed that the first fraction contained mainly serum proteins of the host from which the flukes were obtained. Immunodiffu-

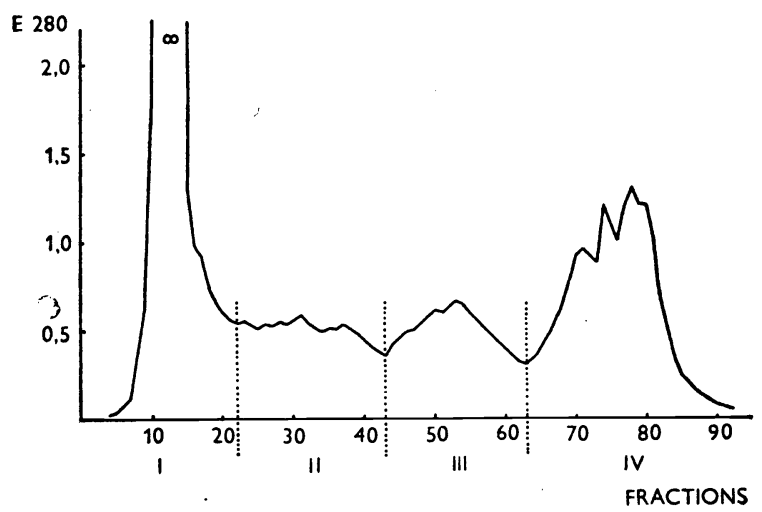

Fig. 1.

Gel filtration on Sephadex G-100 of the crude antigen from adult Fasciola hepatica

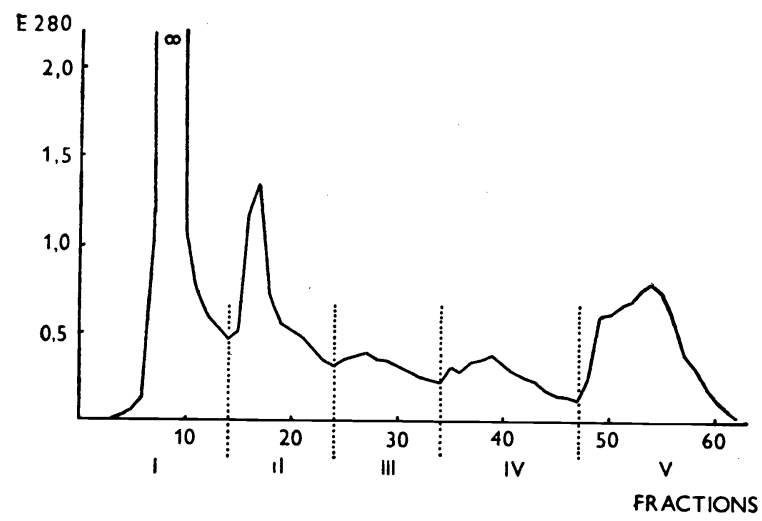

Fig. 2.

Gel filtration on Sephadex G-200 of the crude antigen from adult Fasciola hepatica sion in agar gel according to Ouchterlony using antibody-containing sera from $F$. hepatica-infected animals revealed precipitation lines only in the 2nd and 3rd fractions. Gel filtration on Sephadex G-200 yielded 5 fractions (Fig. 2). Host serum proteins were found, for the most part, in the first fraction and partly in the second. Immunodiffusion according to Ouchterlony revealed precipitation lines with positive sera in the fourth fraction.

The second and third fractions separated on Sephadex G-100 and the fourth fraction separated on Sephadex G-200 were labelled with ${ }^{125} \mathrm{I}$. Before iodination, their protein content was adjusted to $1.5 \mathrm{mg} / \mathrm{ml}$. The protein-bound radioiodine percentage was dependent on the quality of the antigen and on the $\mathrm{Na}^{125}$ I employed for iodination. It ranged from 5.4 to 8 per cent in fractions obtained from flukes partly autolysed in consequence of delayedisolation from theliver and was as high as 23.8 per cent in good-quality antigen prepared from fresh flukes. 
When tested by direct radioimmunodiffusion with positive sera from $F$. hepatica-infected animals and control negative sera, the ${ }^{125} \mathrm{I}$-labelled antigen fractions showed the same specificity and immunoprecipitating properties as the unlabelled fractions.

The stability of the iodinated antigen as evaluated at weekly intervals proved relatively good. The antigen was stable for 4 weeks, and no more than 5 and 6 percent of unreacted radioactive iodide were found after 6 and 8 weeks of storage, respectively. Stored at $4{ }^{\circ} \mathrm{C}$ without a preservative, the iodinated antigen could be used for serological reactions for 5 to 8 weeks. Longer storage resulted in the formation of sediment and a higher rate of release of radioactive iodide.

\section{Discussion}

Crude antigen prepared from $F$. hepatica homogenate contains not only the functional antigen capable of reaction with antibodies produced in the serum of infected animals but also a number of non-standard substances affecting the specificity of reactions. A considerable proportion of the protein content is made up of proteins of the host from which the flukes were obtained. Fractionation and purification of the functional component is a prerequisite for the specific demonstration of antibodies during the early stages of $F$. Hepatica infection.

The antigenic fractions employed for the iodination were checked for specificity by immunodiffusion according to Ouchterlony using sheep and bovine sera from animals infected with common gastric and intestinal nematodes, guinea-pig and rabbit sera from animals infected experimentally with Fascioloides magna and bovine sera from animals infected with Cysticercus bovis. Although the results were invariably negative, the $F$. hepatica antigens prepared in this study cannot be regarded as pure fractions containing only functional antigens.

The quality of the antigen and the protein-bound radioiodine percentage of its protein fraction were considerably affected by the onset of autolytic processes in the flukes. Therefore it is necessary that flukes for the production ov $F$. hepatica antigen should be isolated from infected animals immediately after slaughter and thorougly washed and frozen without delay.

\section{Značení bílkovinné frakce antigenu z Fasciola hepatica radioaktivním izotopem ${ }^{125} \mathrm{~J}$}

Gelovou filtrací na Sephadexu G-100 a G-200 byly separovány bílkovinné frakce antigenu z Fasciola hepatica, které reagovaly s protilátkami ze séra zvířat, invadovaných touto motolicí. Frakce byly značeny ${ }^{125} \mathrm{~J}$ oxidační metodou s chloraminem T. Účinnost značení byla $5,4-23,6 \%$, a to v závislosti na kvalitě motolic použitých $\mathrm{k}$ př́pravě surového antigenu a na $\mathrm{Na}^{125} \mathrm{~J}$ použitého $\mathrm{k}$ jodaci. Testováním ${ }^{125} \mathrm{~J}$ značené bílkovinné frakce prýmou radioimunodifuzí $s$ pozitivními séry zviřat invadovaných $F$. hepatica a kontrolními negativními séry byla prokázána stejná specifičnost jako u neznačené antigenní frakce. Značený antigen byl stabilní po dobu 4 týdnů, po 6 týdnech bylo zjištěno maximálně $5 \%$ a po 8 týdnech $6 \%$ volného radioaktivního jodidu. Značený antigen uchovávaný při $4{ }^{\circ} \mathrm{C}$ byl použitelný pro sérologické reakce po dobu 5-8 týdnů. 


\section{Маркирование белковой фракции антигена из Fasciola hepatica радиоактивным изотопом ${ }^{125} \mathrm{~J}$}

Фильтрацией через гель на сефадексе $Г-100$ и Г-200 были сепарированы белковые фракции антигена из Fasciola hepatica, реагировавшие с антивеществами из сыворотки животных, зараженных упомянутой двуусткой. Фракции были мечены ${ }^{125} \mathrm{~J}$ окислительным методом с хлорамином Т. ${ } \Phi-$ фективность получения меченого соединения достигала $5,4-23,6 \%$, в зависимости от качества двуусток, используемых для подготовки сырого антигена и от $\mathrm{Na}^{125} \mathrm{~J}$, используемого для иодирования. Проверкой ${ }^{125} \mathrm{~J}$ меченной Фракции белка прямой радиоиммунодиффузией с положительными сыворотками инвадированных $F$. hepatica животных и отрицательными сыворотками была установлена одинаковая специфичность по сравнению с немеченной антигенной фракцией. Меченный антиген отличался стабильностью в течение 4 недель. После 6 недель было установлено максимально $5 \%$ и 8 недель спустя - $6 \%$ свободного радиоактивного иода. Меченный антитен, хранимый при $4^{\circ} \mathrm{C}$, можно было использовать для серологических реакций в течение $5-8$ недель.

\section{References}

GRELCK, H.: Beurteilung der koproskopischen und serologischen Methoden zur Diagnose der Rinderfasciolose. Thesis, FU Berlin 1976.

KOCH, H. W.: Untersuchungen über die Brauchbarkeit von Haemagglutination, Flocculation, Micro-Agar-Präzipitation und der Immunofluoreszenz zum frühzeitigen Nachweis der Fasciolose des Rindes. Inaug. Dissertation, FU Berlin 1969.

LOWRY, O. H. - ROSENBROUGH, N. J. - FARR, A. L. - RANDAL, R. J.: Protein measurement with the Folin phenol reagent. J. Biol. Chem., 193, 1951: 265-275.

McCONAHEY, P. J. - DIXON, F. J.: A method of trace iodination of proteins for immunologic studies. Int. Arch. Allergy, 29, 1966: 185-189.

MOVSESIJAN, M. - BOROJEVIC, C.: Antigenic analysis of Fasciola hepatica: Extraction and fractionation. In Isotopes and Radiation in Parasitology III, IAEA Vienna 1973, p. 11-22.

SCHMIDT, H. E. - TEICHMANN, B. - VOGT, R. - HERZMANN, H.: ${ }^{131} \mathrm{~J}$-Markierung von Antikörpern nach der Chloramin T Methode. Modellexperimente mit Kaninchen-Gammaglobulin und Anti-Pferdeserumalbumin-Antikörpern. Isotopenpraxis, 10, 1974: 401-407.

WILLIAMS, J. S. - SADUN, E. H. - GORE, R. W.: A radioactive antigen microprecipitin (RAMP) assay for schistosomiasis. J. Parasit., 57, 1971: 220-232. 